Uzelac Ozren*

https://orcid.org/0000-0001-6991-1644

Dukić Mijatović Marijana ${ }^{* *}$

https://orcid.org/0000-0001-9535-2962
UDK: 351.941:368.81(410)

Original scientific paper

DOI: $10.5937 /$ ptp2104001U

Received: 20.09.2021.

Approved on: 29.11.2021.

Pages: 1-15

\title{
PRACTICE OF EXTENDED COMPETENCE OF THE OMBUDSMAN FOR THE FINANCIAL SERVICES OF THE UNITED KINGDOM IN THE FIELD OF INSURANCE
}

\begin{abstract}
In this paper, the authors discuss the decision-making method of the UK Financial Services Ombudsman enabling more favourable outcomes for an insured person in relation to the strict application of law. The authors delineate the manner in which the Ombudsman and the courts act and present specific examples in which the Ombudsman has recognized some rights to the insured whose exercising they themselves did not demand from the insurer. In the practice of the Ombudsman, there are numerous examples in which disputes arose due to a poor understanding of the breadth of the insurance coverage by the insured, the quality and scope of the damage repair service, a restrictive interpretation of the subject of insurance by the insurer. The circumstances on which the Ombudsman made decisions in disputes were based on the standard of a "vulnerable insured person" and a free belief of this body regarding the existence of unfulfilled expectations, which could contribute to the further improvement of the legal framework for the protection of the insured persons.
\end{abstract}

Keywords: a vulnerable insured person, insurer, the Ombudsman, consumers protection, costs

\footnotetext{
${ }^{*}$ LLD, Assistant Professor, The Faculty of Economics in Subotica, The University of Novi Sad, Serbia, e-mail: ozren.uzelac@ef.uns.ac.rs

${ }^{* *}$ LLD, Associate Professor, The Faculty of Technical Sciences, The University of Novi Sad, Serbia, e-mail: marijana.mijatovic@uns.ac.rs

(c) () (C)2021 by the authors. This article is an open access article distributed under the terms and conditions of the Creative Commons Attribution (CC BY) license (https://creativecommons.org/ licenses/by/4.0/).
} 


\section{Introduction}

During the twentieth century, awareness of the need for an independent body to protect certain rights of citizens has matured for decades. Thus, in 1967, the Office of the Parliamentary Ombudsman was formed in Great Britain, after which, until the end of the 1970s, ombudsmen in the field of health care, local self-government, etc. were formed. In the field of insurance, the British Insurance Law Association (BILA) held a colloquium in July 1975 on "Insurance and the Consumer" to discuss the success of an independent grievance redress system, after which a representative of the insurance company The Guardian Royal Exchange, in September of the same year, sent a memorandum to the insurance companies of Great Britain on the need to establish the institution of the Insurance Ombudsman (Mendelowitz, 2014, p. 67). After a few years, in 1981, three insurers (Guardian Royal Exchange, General Accident i Royal Insurance) formed the Insurance Ombudsman Bureau, which was supposed to resolve clients "complaints about insurers" behaviour independently, and without compensation. It was a voluntary, professional and non-governmental initiative supported by the National Consumer Council of Great Britain. Since at that time there was no other body to supervise the implementation of business codes in the field of investment and insurance, most other insurers joined the organization (Penina Summer, 2009, p. 1).

With the entry into force of the Financial Services and Markets Act in $2000,{ }^{1}$ the Financial Services Authority established the Financial Ombudsman Service (Ombudsman) as the only body to deal with consumer complaints related to all types of financial services.

It should be borne in mind here that English insurance law developed through the creation of customary insurance law during the 18th and 19th centuries, only to be partially codified in 1906 by the Marine Insurance Act (hereinafter: ZPO). Courts in the early 90s of the 20th century took the view that it applies to all types of insurance because it represents insurance codification of customary law (common law) ${ }^{2}$. However, the principles precisely and understandably defined in this Law posed a problem to the courts in their application with the emergence of new modern tendencies in the development of insurance rights, i.e. new rules by which the solutions from that Law no longer met the needs of the modern consumer market (Jovanović \& Slavnić, 2015, p. 154).

\footnotetext{
${ }^{1}$ Part XVI, Art. 225-234 /Financial Services and Markets Act 2000

${ }^{2}$ Lord Mustill's rationale in the Pan Atlantic Insurance Co Ltd v Pine Top Insurance Co Ltd [1995] 1 AC 501, p. 518; Judge Steyn's rationale in the Banque Keyser Ullmann SA v Scandinavia (UK) Insurance Co Ltd [1990] 1 QB 665, p. 701.
} 


\section{Delimitation of the manner of action of courts and ombudsmen}

The analysis of the manner in which the Ombudsman acts in the exercise of his legal powers in this paper does not refer to procedural rules and principles, but to the principles on which the decisions of this body are based. For the purposes of this paper, the basic meaning of the neglected Latin term modus operandi that it has in the work of the police or in some other scientific disciplines will be, but the definition of the term "modus" as a possibility or way to solve something (Serbian Language Dictionary, 2007, p. 725) in this work, resolving a dispute between the insured and the insurer before the Ombudsman of the United Kingdom.

First of all, it should be borne in mind that the Rulebook of the Financial Supervision Agency stipulates that the Ombudsman resolves complaints by applying standards that, in his opinion, are fair and reasonable in all circumstances of the case (Financial Conduct Authority's Handbook of rules and guidance, 2016, 364R). A fair and reasonable decision of the Ombudsman is based on relevant laws and by-laws, rules, guidelines and standards of the supervisory body, business codes and what the Ombudsman considers to be good practice of insurance activities at the time of the complaint (Financial Conduct Authority's Handbook of rules and guidance, 2016, 364R).

There are fundamental differences in the conduct of the UK Financial Services Ombudsman and the courts with regard to lawsuits against financial service providers. The Ombudsman makes his decisions by applying what he considers fair and reasonable, taking into account all the circumstances of the case. Thus, the Ombudsman is not obliged to apply strict rules of interpretation if their application would nullify the legitimate (subjective) expectations of consumers (Mendelowitz, 2014, p. 71).

It is a well-known moral assumption that a policyholder does not enter into an insurance contract for commercial gain (Merlin, 2015, p. 2). That is, the essence of insurance is to protect policyholders from sudden and unexpected disasters that create a state of economic and personal vulnerability of policyholders.

Given a large number of disputes with similar circumstances and consequences, the Financial Services Ombudsman has built certain standards in decision-making over time.

Unlike the UK, the Ombudsman in Germany can never make a decision as an expression of goodwill (Kullanzentscheidung), "but it may informally recommend to the insurer that accepting a client's compensation claim may be a gesture of goodwill," (Gal, 2014, p. 40). The Ombudsman's 
extended jurisdiction over court proceedings is reflected in the fact that the UK Ombudsman can pass judgement for damages for stress or problems even when the complainant has not claimed such compensation. On the other hand, the court can only decide on the merits of the claims in accordance with the law and cannot award those types of damages that the plaintiff did not even request in the claim. Thus, the court cannot oblige the insurer to pay damages for delaying the liquidation of the claim, because the obligation under the insurance policy arises from the occurrence of the insured event that causes the damage, and any delay in payment of damages is compensated by interest from the date of damage until payment, how ever long that period of time. ${ }^{3}$ In addition to the above, the dispute in The Italia Express ${ }^{4}$ established that there is no right to compensation for stress caused by delays in the liquidation of the claim because the peace of the insured is not a specific goal of the insurance contract. If the insurer deserves a penalty that is stricter than the interest, the competent supervisory body should decide on that.

\section{Vulnerable Insured}

According to the Financial Services Ombudsman, the insured is in a vulnerable position due to personal circumstances such as age, physical or mental health, liability and events that significantly change the regular life such as job loss, break up with a partner or death of a loved one, why they need additional attention, but also the support of companies and the services they use (Financial Ombudsman Service - Iss. 127, 2015, p. 3).

According to the definition of the Agency for Supervision of Behavior in the Financial Sector, a vulnerable consumer is someone who, due to his personal circumstances, is particularly exposed to harmful effects, especially when the service provider does not act with an adequate level of attention (Financial Conduct Authority, 2015, p. 20). Consumer protection regulations rely on the definition of the average or typical consumer and what they expect, understand or behave. Consumers in vulnerable circumstances are often unable to substantially represent their interests and are more likely to be exposed to harm than the average consumer. This is an area where service providers can take appropriate action and create good outcomes for consumers.

\footnotetext{
${ }^{3}$ Sprung v Royal Insurance (UK) Ltd (1997) CLC 70; Pride Valley Foods Ltd v Independent Insurance Co Ltd [1999] Lloyd's Rep I.R 120; England v Guardian Insurance Ltd, [2000] Lloyd's Rep I.R. 404; Normhurst Ltd v Dornoch Ltd [2005] Lloyd's Rep I.R. 27 i Tonkin v UK Insurance Ltd.

${ }^{4}$ [1992] 2 Lloyd's Rep 281.
} 
The Ombudsman may also, by his decision, oblige the insurer to, in addition to the basic claim and the related interest (if any), pay special compensation for the greater vulnerability of the insured caused by the poor quality of the insurer's service. In dispute no. 127/1 (Financial Ombudsman Service - Iss. 127, 2015, pp. 4-5) on vacation in Spain, the insured was taken to the hospital for his psychotic condition due to, as the hospital doctor said, the recent death of his mother and his divorce. On the other hand, the insurer obtained the opinion of the general practitioner who stated that the insured had been suffering from depression for a long time and refused to pay the hospital costs for treatment due to the health condition that existed before concluding the insurance policy. When the insured learned of the insurer's decision, he voluntarily left the hospital and slept on the street until his sister came for him and took him home to the UK. The ombudsman considered that the insurer could have done more for the insured and that he could have organized his transfer to the state hospital and that he could thus have avoided being on the street. Since, in the Ombudsman's opinion, the insurer failed to prove that the cause of the specific health condition was excluded from the coverage, the Ombudsman obliged the insurer to reimburse the insured for medical expenses and interest, as well as compensation for vulnerability due to the insurer's refusal to pay compensation.

The extent to which the principle of fairness and reasonableness plays a decisive role in the protection of insured persons when deciding on the Ombudsman can be seen in the area of fulfilling contractual obligations and reporting important facts to the insurer. This especially refers to the case when, in the opinion of the insurer, there is a worsening of the risk and the right of the insurer to narrow the insurance coverage or cancel the insurance contract. In dispute no. 127/3 (Financial Ombudsman Service - Iss. 127, 2015, p. 6-7), the insured was admitted to the hospital due to an ankle fracture, and due to degenerative changes, he had to be hospitalized for two months. During his stay in the hospital, there was a burglary in his house, so the insured filed a claim with the insurer for compensation for the stolen items. The insurer rejected the claim with the explanation that the conditions of the insurance were the obligation of the insured not to leave the house empty. The term "empty house" is defined in the insurance terms in such a way that "the policyholder, members of his family or another authorized person do not sleep in it for a period longer than 30 days." The Ombudsman accepted the insured's claim for compensation, taking into account that the insured's stay in the hospital was sudden, that he did not act negligently and that his son visited the house several times while he was in the hospital. The Ombudsman considered it unfair for the insurer to refuse to pay this claim, and obliged the insurer to pay it in full. 
In the next dispute no. 127/9 (Financial Ombudsman Service - Iss. 127, 2015, pp. 13-14) it was a question of whether the insured reported an important fact and whether the insurer had the right to refuse his obligation. The insured moved into a house on a new farm. His wife fell ill and could not work, which is why they leased several auxiliary buildings to other people to compensate for their income. Soon after they moved in, the fire destroyed one of the barns and most of its contents, including parts for the machines, kept there by a neighbour. The fire also damaged parts of the family home. When the insured filed a claim, the insurer rejected it, claiming that the insurance coverage did not apply to the business purposes of the insured property and that the insured did not state that the barn would be used for business purposes. On the other hand, the insured referred to the fact that he specifically mentioned to the insurer when concluding the insurance contract that he would lease the buildings. The Ombudsman requested from the insurer the procedures on the basis of which the sale of the insurance policy in question took place. From the procedures, they determined that there was a question about the purpose of the insured facilities, but that it was not set up for the insured, nor was a telephone conversation between the insured and the insured recorded. On the other hand, the insured claimed that in a telephone conversation he mentioned his wife's illness and the intention to rent facilities on the farm in order to supplement his income. Given that the insurer did not have a record of the telephone conversation, and that the insured was consistent in his claims, the Ombudsman decided to support the insured's claim for damages. The ombudsman considered that it was obviously a mistake that caused the insured a great deal of stress at an already difficult time for him, which is why his children and his sick wife lived in a damaged house. The insured also took a loan to pay the neighbour for the damaged car. Taking all the above into account, the Ombudsman obliged the insurer to pay the insured the damage in accordance with the terms and limits of the insurance policy, compensation for the problem caused by their mistake, as well as interest on the loan taken out by the insured.

In dispute no. 127/11 (Financial Ombudsman Service - Iss. 127, 2015, pp. 16-17), the vulnerability of the insured was manifested due to poor quality work on repairing the insured damage. The insured's house was flooded after a series of severe storms and heavy rainfall, with the ground floor, and especially the kitchen, severely damaged. She filed a claim for damages under the household insurance policy. The insurer went to the scene, agreed with the necessary repairs and agreed with the contractor. The insurer also provided an alternative - temporary accommodation for the insured and her six-year-old daughter during the works. After a few weeks, the insured and her daughter returned to their house, but after a few days, she noticed numerous problems. Parts of the kitchen 
wall were not secured, the floor coverings were not at the same level and there was still an intense smell of moisture. Dissatisfied with the quality of the performed repair works, the insured contacted a local construction company whose services she had used before. They believed that the smell of moisture was coming from the gypsum boards damaged in the flood, which the contractor hired by the insurer had not removed. They also discovered that the pipe was leaking and suggested that the insured install air valves to try to get rid of the smell of moisture, but they refused to do any additional work in the kitchen because they thought that the previous works were poorly performed. When she approached the insurer, they refused any additional help and pointed out that the problem with the floor coverings had existed before and considered that the insured had damaged parts of the kitchen wall by installing air valves and that the pipe leak was due to regular wear. A third construction company, hired by the insured, confirmed that the wrong type of plaster was used on the wall, which also worsened the problem of pipe corrosion. The insurer considered that he had fulfilled everything that was his obligation and rejected further requests of the insured. At that time, the insured woman lived without using the kitchen for more than a year and called her doctor because of the stress she suffered.

Based on the photographs, the Ombudsman determined that the works were not performed in a satisfactory quality and that the claims of the insured were justified. The insurance company also submitted three reports from independent construction companies, which confirmed that the quality of the work performed was poor.

The Ombudsman pointed out that the insurer was responsible for the quality of the contractor's work, and concluded that the insurer had not acted fairly when he refused to accept responsibility for bringing the damage into proper condition and take care of the insured and her daughter until the kitchen was in good condition.

In addition to obliging the insurer to repair all the identified damages, the Ombudsman considered that the insured and her daughter were vulnerable for a long period of time due to poor service of the insurer, and ordered the insurer to pay the insured $£ 750$ due to continuous disturbance and stress she suffered.

\section{Unfulfilled expectations of the insured}

It is a common opinion that the biggest risk for every insurance policyholder, and especially for a natural person, is to have an insurance policy and to pay premiums regularly, without having any or almost no insurance coverage (Todorović Simeonidis, 2014, p. 256). 
A special problem with insurance contracts is the non-transparency of general and special insurance conditions that the insured does not know at all or only superficially browses when concluding the insurance policy, without essentially knowing or understanding them. Although the conditions of insurance today are quite similar, as claimed in our legal theory, there is a danger that the insurance contract will include provisions aimed at protecting the insurer from larger obligations to the detriment of the legitimate interests of the insured (Pak, 2004, p. 192). This is especially true when it comes to the refusal or unfounded reduction of the insurer's obligations to the insured.

In the practice of the Ombudsman of the United Kingdom, there are numerous examples in which disputes arose due to a poor understanding of the breadth of insurance coverage by the insured, the quality and scope of the repair service, restrictive interpretation of the insurance subject by the insurer or other insurance conditions. In the following, we will present the details of these disputes.

In dispute no. 07/01 (Financial Ombudsman Service, Iss. July, 2001, pp. 6-7), the insurer did not explain to the insurance contractor that the insurance coverage is valid for individual trips lasting for up to 30 days and that it does not cover claims from dangerous activities, including riding motorcycles with over $125 \mathrm{cc}$. It took the insurer three weeks to issue the policy and send it to the insurance contractor. Since he was on the road at the time, his sons could not check before the trip to the United States whether the insurance policy corresponded to their needs, because they wanted the insurance coverage to cover the trip to the United States. A month later, one of the sons of the insurance contractor travelled to Australia, where he suffered a fatal car accident while riding a motorcycle. The policyholder has filed a claim for repatriation and funeral expenses and compensation of $£ 30,000$ for the death with the insurer. The insurer explained that due to the said exclusion, the policyholder has no coverage. However, he accepted that he did not sell and issue the insurance policy fairly, nor did he explain the conditions of the insurance, and he accepted to reimburse the costs of repatriation and burial as a gesture of goodwill.

The insurance contractor pointed out that he decided to conclude an insurance policy for a trip to the USA due to the length of the trip, to which the insurer replied that he would not invoke the mentioned exclusion if the accident happened in the USA.

However, during the second trip, the contractor realized that the insurance policy did not cover all types of dangerous activities, which is why he had the opportunity to check whether the insurance policy meets his needs and to request an extension or supplement of the necessary coverage. In such circumstances, the Ombudsman of the United Kingdom considered that the insurer's 
offer to reimburse the costs of repatriation and burial was reasonable and that he had no obligation to pay the insured benefit due to the death of his son.

In the UK legal system, a court may apply the UK Regulation on Unfair Contractual Terms of Consumer Contracts of 1999 to determine whether it is fair to exclude a certain dangerous activity from coverage. Thus, in the dispute between Bankers Insurance Co. $v$ South, ${ }^{5}$ the court decided that the exclusion of accidents of "motorized vessels" was stated in simple and understandable language and that this exclusion was the essence of the travel insurance in question, which is why it was not analysed. The court added that it was not an unfair and incorrect exclusion, because the person who planned the vacation could read it if he wanted to. These are logical views of the court, but the Ombudsman can take completely different views that are more in favour of consumers.

In the next dispute no. 18/22 (Financial Ombudsman Service, Iss. July, 2002 , p. 20) oil seals on the camshaft broke and there was a leak of oil on the belt in the housing at the end of the engine, which was closed with a seal. The insured performed the necessary repairs: steam cleaning of the components and replacement of the shaft seal and oil seal, and then demanded from the insurer reimbursement of the repair costs. The insurer rejected the claim, claiming that the insurance conditions excluded from the coverage "external oil leakage." He explained that he would have covered the repair costs if they had been caused by an internal oil leak, such as a leak from a torn seal head into the cylinder, however, it does not cover any leaks outside the engine block, oil tank and cylinder head.

The Ombudsman considered that the insurer interpreted the exclusion in question as too restrictive. The Ombudsman considered that it was unreasonable to expect the policyholder to understand the narrow distinction between different types of oil leaks and disagreed with the insurer's claim that oil leaks in the housing due to a seal failure were considered "external."

In dispute no. 18/24 (Financial Ombudsman Service, Iss. July, 2002, p. $21)$, there was a problematic way in which the insurer addressed the loan insurance policy and the breadth of insurance coverage. In the specific case, the insured concluded the insurance for his own protection in case of impossibility to repay the loan. His lender concluded an insurance policy "for the risks of death, incapacity for work and unemployment." When the insured was fired, he filed a claim against the insurer, who rejected it, claiming that the insurance conditions covered unemployment only in the event of redundancy.

${ }^{5}$ [2003] EWHC 380. 
In terms of insurance, the term "unemployed" was defined as "without a job directly due to redundancy or the collapse of the company." The insurer also referred to the definition of "redundancy": "employment terminated solely due to the employer's decision to stop or reduce the activities you are engaged for." The insured complained that he became redundant because he received compensation for redundancy, but the insurer did not accept his objection. The insurer pointed out the proof of the former employer of the insured according to which the insured was fired because he was incapable of performing his obligations in a satisfactory manner.

The Ombudsman found the following: Although part of the title of the insurance policy contained the words "unemployment risk" in the description of coverage, the insurance conditions did not provide this type of coverage, but limited coverage only to unemployment due to redundancies. This limitation was only noticeable after a careful reading of the insurance conditions, including the definitions section. The ombudsman also found that the insurer called and advertised this type of insurance as if it covered all causes of unemployment. Given this fact, the insurer had to specify to the lender, who sold these insurance policies, the actual scope of coverage with which he would inform the potential policyholders before concluding the insurance contract. Finally, that the insured did not lose his job through no fault of his own.

For the above reasons, the Ombudsman considered that the lender did not draw the policyholder's attention to the limitations of coverage and accepted the claim of the insured that the insurance policy was sold to him in a state of delusion. In addition, the Ombudsman considered that it was not fair to return only the premium to the insured, but also to pay him full compensation because if he had known that the insurance policy did not cover all causes of unemployment, he would have concluded wider coverage with another insurance company.

In dispute no. 133/1 (Financial Ombudsman Service, Iss. 133, 2016, pp. $3-4)$ the insured damaged his vehicle by pouring the wrong type of fuel and demanded from his Casco insurer reimbursement of repair costs. However, the insurer rejected the claim, claiming that the insurance policy no longer covered that type of damage. The ombudsman asked the insurer to provide him with the information he sent to the insured before the extension of the insurance policy, together with all changes and amendments to the insurance conditions. The cover letter submitted together with the other documentation contained the following notice: "You must carefully check all the details. If they are correct, you do not have to take any further action." As the disputed exclusion was not mentioned or highlighted anywhere, and was only after a few pages, as the 
last of all exclusions, the Ombudsman considered that it was not reasonable to expect someone to read 40 pages to check whether the insurance coverage had changed. Therefore, the Ombudsman decided that the insurer did not do enough in the given circumstances to inform the insured that his insurance coverage was narrowed for the risk of using the wrong type of fuel and ordered the insurer to act with this claim as if the exclusion did not exist.

The Ombudsman may be more lenient in interpreting insurance conditions and in the case of luggage insurance, in which type of insurance very few insured persons are aware of the standard exclusion of lost or stolen luggage (for example, when luggage left in a motor vehicle unlocked and unattended) and to compensate performed according to the actual value, and not the newly acquired value or after deduction of the franchise (Penina Summer, 2009, p. 89). In dispute no. 63/8 (Financial Ombudsman Service, Iss. 63, 2007, pp. 1011) of the insurance conditions stipulated that luggage must be stored "in a locked accommodation" or "in a locked or covered compartment/trunk of a motor vehicle." In this particular case, the insured travelled to New Zealand in a camper van, so the Ombudsman decided that it was more of a vehicle than accommodation and that because he did not have a luggage compartment or trunk where personal belongings would not be visible, he did not accept the claim.

In dispute no. 69/4 (Financial Ombudsman Service, Iss. 69, 2008, pp. 7-8), the insured concluded a contract for insurance of an extended product warranty for the purchased leather set in three parts. The set was covered by the manufacturer's warranty for the first twelve months and four additional years of extended warranty under the insurance contract against any accidental damage to the material caused by "separation, splitting, burns, perforation and pets", as well as "structural damage" caused by the number of its special features, including "broken zippers." Less than a year after the purchase, the insured discovered that the leather cover on the sofa was damaged, at the place where the metal part of the adjusting mechanism rubbed against the leather cover. The manufacturer has repaired this defect free of charge under its warranty. The same defect occurred after eight months when the manufacturer's warranty expired, due to which the insured filed a claim with the insurer. The insured reported that the damage occurred after previous repairs and that it is necessary to repair the sofa frame because the leather is poorly marked and the zippers on the backrests are damaged.

The insurer rejected the claim, claiming that the damage was caused by the poor quality of the manufacturer's repairs and that the extended warranty insurance contract did not cover the manufacturer's "negligent omission." 
The ombudsman analysed the insurance conditions and concluded that they were very poorly worded, as there was great uncertainty as to what the insurer wanted to cover and how the various exclusions were applied. Due to the above, we can say that the Ombudsman's decision in this dispute coincides with the legally prescribed interpretation of the terms of the contract in case of unclear provisions drawn up by the insurer, and he considered that the terms of the insurance must be interpreted in the most favourable way for the policyholder and with the most sensible expectations he had at the time of concluding the insurance contract.

The unfulfilled expectations of the insured are best reflected in the poor quality of the insurance service provided during the repair and compensation of damage, due to which the insured suffers the damage again. In dispute no. 130/3 (Financial Ombudsman Service, Iss. 133, 2015, p. 6) after severe damage to the roof during the storm, the eighty-year-old insured who lived alone filed a claim for damages under her household insurance policy. During the damage assessment, the insurer recommended that she arrange a temporary repair of the roof. Later, the insurer agreed to compensate for the damage that occurred inside the house, but they rejected part of the compensation claim, claiming that the roof was in a bad - unmaintained condition before the storm. A few months later, the roof of the insured leaked again and caused additional damage to the interior of the house. She called the insurer, but he refused to help her because the damage was caused by poor temporary roof repairs and the insured's obligation was to carry out permanent repairs. However, the insurer could not provide any evidence that the insured had been warned that she needed to carry out a permanent roof repair, and given her age and the fact that she lived alone, they should have done so. The ombudsman obliged the insurer to repair the damage as if it were a claim for damages.

\section{Conclusion and significance for the Republic of Serbia}

Based on the analysis of the decision-making manner of the Financial Services Ombudsman of the United Kingdom, several conclusions can be drawn. It is an institution of out-of-court settlement of disputes between consumers of insurance services and insurers that are subject to mandatory supervision by the Financial Supervision Agency and fall under the mandatory competence of the Ombudsman. Second, the extended competence of the UK Ombudsman in relation to the strict application of regulations differs from the way in which the equivalent bodies of the continental legal systems decide. Third, the non-obligation to apply regulations, business practices and 
business codes in relation to the free belief in a fair and balanced settlement of disputes contributes to (sometimes) unexpected outcomes for both the insured and the insurer. Fourth, deciding exclusively on the principle of equo et bono without strict application of regulations and precedents inevitably leads to uncertainty regarding the consistency of decisions. Fifth, the decisions of the Ombudsman can be far harsher for the interests of insurers and more favourable for the insured in relation to the outcome by strict application of insurance regulations and conditions. Sixth, we believe that such a system of the Ombudsman forces insurers to be more conscientious and careful when executing insurance contracts.

Having in mind the high specialization of this institution for the insurance business, we believe that it should be introduced in the domestic system of protection of insurance service users. The ombudsman should be a person, who should be recommended for this position by the highest positions in the work of the judiciary, and his assistants should be experts in insurance law. Membership in the Ombudsman should be mandatory for all entities whose operations, in accordance with the Law on Insurance, are subject to the supervision of the National Bank of Serbia.

\section{Uzelac Ozren}

Docent, Ekonomski fakultet u Subotici, Univerzitet u Novom Sadu, Srbija

\section{Dukić Mijatović Marijana}

Vanredni profesor, Fakultet tehničkih nauka, Univerzitet u Novom Sadu, Srbija

\section{PRAKSA PROŠIRENE NADLEŽNOSTI OMBUDSMANA ZA FINANSIJSKE USLUGE VELIKE BRITANIJE U OBLASTI OSIGURANJA}

REZIME: U ovom radu autori razmatraju način odlučivanja Ombudsmana za finansijske usluge Velike Britanije, koji omogućuje povoljnije ishode po osiguranika u odnosu na striktnu primenu zakona. Autori vrše razgraničenje načina postupanja ombudsmana i sudova, te izlažu konkretne primere 
u kojima je Ombudsman osiguranicima priznao i neka prava čije ostvarivanje oni sami nisu zahtevali od osiguravača. U praksi Ombudsmana postoje brojni primeri u kojima su sporovi nastajali usled lošeg razumevanja širine osiguravajućeg pokrića od strane osiguranika, kvaliteta i obima usluge popravke štete, restriktivnom tumačenju predmeta osiguranja od strane osiguravača. Okolnosti u kojima je Ombudsman donosio odluke u sporovima zasnivane su na standardu „ranjivog osiguranika” i slobodnom uverenju ovog organa u vezi sa postojanjem neispunjenih očekivanja, što može doprineti daljem unapređenju pravnog okvira zaštite osiguranika.

Ključne reči: ranjivi osiguranik, osiguravač, Ombudsman, zaštita potrošača, troškovi.

\section{References}

1. Gal, J. (2014). The German Insurance Ombudsman System. In: Samim Ünan (ed.), Alternative Dispute Resolution Systems Regarding Private Insurance (pp. 9-44). Istanbul: Sigorta Hukuku Türk Derneği

2. Financial Services and Markets Act 2000. Downloaded 2021, September 12 from https://www.legislation.gov.uk/ukpga/2000/8/contents

3. Financial Ombudsman Service. Ombudsman News - Issue July for 2001. Downloaded 2021, September 15 from https://www.financial-ombudsman.org.uk/files/2795/7.pdf

4. Financial Ombudsman Service. Ombudsman News - Issue July for 2002. Downloaded 2021, September 15 from https://www.financial-ombudsman.org.uk/files/2805/18.pdf

5. Financial Ombudsman Service. Ombudsman News - Issue no. 63 for 2007. Downloaded 2021, September 15 from https://www.financial-ombudsman.org.uk/files/2898/63.pdf

6. Financial Ombudsman Service. Ombudsman News - Issue no. 69 for 2008. Downloaded 2021, September 15 from https://www.financial-ombudsman.org.uk/files/2904/69.pdf

7. Financial Ombudsman Service. Ombudsman News - Issue no. 127 for 2015. Downloaded 2021, September 15 from https://www.financial-ombudsman.org.uk/files/2858/issue_127.pdf

8. Financial Ombudsman Service. Ombudsman News - Issue no. 130 for 2015. Downloaded 2021, September 15 from https://www.financial-ombudsman.org.uk/files/2855/issue130.pdf 
9. Financial Conduct Authority. Occasional Paper No. 8: Consumer Vulnerability - for 2015. Downloaded 2021, September 17 from https:// www.fca.org.uk/publication/occasional-papers/occasional-paper-8.pdf

10. Financial Conduct Authority's Handbook of rules and guidance. Dispute resolution: Complaints (DISP), Release 5 for 1 April 2016. Downloaded 2021, September 17 from https://www.handbook.fca.org.uk/handbook/ DISP.pdf

11. Financial Ombudsman Service. Ombudsman News - Issue no. 133 for 2016. Downloaded 2021, September 15 from https://www.financial-ombudsman.org.uk/files/2851/issue133.pdf

12. Jovanović, S., \& Slavnić, J. (2015). Reforma prava osiguranja u Engleskoj i novine $u$ vezi sa prijavom bitnih informacija osiguravaču, pre zaključenja potrošačkih ugovora o osiguranju [Reform of insurance rights in England and news regarding the application of important information to the insurer, before the conclusion of consumer insurance contracts]. Evropsko zakonodavstvo, 13 (54), pp. 153-166

13. Mendelowitz, M. (2014). Resolving Consumer Insurance Complaints in the UK - The Financial Ombudsman Service. In: Samim Ünan (ed.), Alternative Dispute Resolution Systems Regarding Private Insurance (pp. 66-76). Istanbul: Sigorta Hukuku Türk Derneği

14. Merlin F, W. (2015). Unfair Claims Practices - A First Party Perspective. Downloaded 2015, August 10 from http://merlinlawgroup.com/sites/ merlinlawgroup/resources/unfair-claims-practices.pdf

15. Nikolić, M. (ed.) (2007). Rečnik srpskoga jezika [A Dictionary of Serbian Language]. Novi Sad: Matica srpska

16. Pak, J. (2004). Pravna zaštita korisnika usluga osiguranja [Legal protection of insurance service users]. In: Slavnić, J. \& Šulejić, P. (eds.) Privreda $i$ pravo osiguranja u tranziciji [Economy and insurance law in transition] (pp. 187-204). Beograd: Udruženje za pravo osiguranja Srbije i Crne Gore

17. Penina Summer, J. (2009). Insurance Law And The Financial Ombudsman Service: Thesis for the degree of Doctor of Philosophy. Southampton: University of Southampton, Faculty of law, arts \& social sciences

18. Todorović Simeonidis, M. (2014). Imenovani ugovori u neživotnom osiguranju: poseban osvrt na rešenja u grčkom ugovornom pravu osiguranja [Nominant non-life insurance contracts: a special look at solutions in Greek contractual insurance law]. In: Jovanović, S., Marano, P. \& Žarković, N. (eds.) Moderno pravo osiguranja: tekuća pitanja i trendovi [Modern insurance law: current issues and trends] (pp. 256-271). Beograd: Udruženje za pravo osiguranja Srbije 